\title{
Estimation of age, growth and fishing season of a Paleolithic population of grayling (Thymallus thymallus) using scale analysis
}

\author{
Guillaud Emilie ${ }^{1,{ }^{*}}$, Elleboode Romain ${ }^{2}$, Mahe Kelig ${ }^{2}$, Bearez Philippe ${ }^{1}$
}

${ }^{1}$ Archéozoologie, archéobotanique : Sociétés, pratiques et environnements (UMR 7209), Sorbonne Universités, Muséum national d'histoire naturelle, CNRS, CP 56, 55 rue Buffon, 75005 Paris, France.

${ }^{2}$ IFREMER, Fisheries Laboratory, Sclerochronology centre, 150 quai Gambetta, BP 699, 62321 Boulogne-sur-Mer, France

* Corresponding author : Emilie Guillaud, email address : emilie.guillaud@mnhn.fr

\begin{abstract}
:
The fish remains sampled from archaeological sites are generally the result of human food refuse; therefore, the study of retrieved fish scales may provide reliable information on the season of capture and on paleoclimate and paleoenvironmental changes. Among Western European freshwater fishes, the grayling, Thymallus thymallus, has the most easily recognizable scales and is a commonly recovered species from Paleolithic contexts. This study, therefore, is based on the growth pattern analysis of modern and archaeological scales from grayling specimens. The modern specimens were collected monthly in France $(n=22)$, Switzerland $(n=16)$, Finland $(n=20)$ and Sweden $(n=10)$. Scale growth patterns were measured using numerical analysis to a high accuracy. The results showed that the archaeological population of grayling is closer to the present Finnish population. Furthermore, the comparison of seasonal growth patterns between current and archaeological European populations, demonstrated that graylings were normally captured during the spring at Le Taillis des Coteaux Magdalenian site. This type of approach can be used to understand environmental conditions at a low spatial scale, and also to help identify fishing seasons during archaeological periods.
\end{abstract}

Keywords: France, Le Taillis des Coteaux, marginal increment analysis, scales, scalimetry, Sclerochronology, Thymallus thymallus, Upper Paleolithic 


\section{Highlights}

Sclerochronological analysis of fish scales.

We used a modern referential alongside archaeological scales from the Magdalenian period.

We demonstrated the usefulness of using scales.

We developed a model enabling the estimation of the seasonality of grayling capture.

We evidenced that spring was the most productive period for catching grayling at Le Taillis des Coteaux cave.

Keywords : Sclerochronology, scalimetry, Le Taillis des Coteaux, Upper Paleolithic, scales, Thymallus thymallus, France, marginal increment analysis.

\section{Introduction}

In Western European Late Pleistocene sites fish remains are abundant, especially from the Magdalenian period (e.g. Cleyet-Merle, 1990; Le Gall, 1999), and they have proved to be extremely useful in the study of human occupation seasonality. These archaeological studies use the growth patterns of calcified structures (vertebrae, scales and otoliths) to estimate the season of capture and infer sequential or seasonal activities (Van Neer et al., 1999). The growth increment studies of fish remains from archaeological sites are usually based on vertebrae (Desse \& Desse-Berset, 1993) or otoliths (Smith, 1983; Hales \& Reitz, 1992; Bolle et al., 2004), and generally focus on seasonality estimation (Desse \& Desse-Berset, 1993; Van Neer et al., 1993) to provide an overview of subsistence resources throughout the yearly occupation of prehistoric sites (Casteel, 1972; Wheeler \& Jones, 1989; Van Neer et al., 1999). Growth rate analysis is less frequently performed (Hales \& Reitz, 1992). The use of these calcified structures to estimate the period of the archaeological fish catch raises significant conservation issues related to global warming because temperature is a crucial parameter for fish survival (Wood \& McDonald, 1997; Buisson et al., 2008). They raise also methodological difficulties such as the representativeness of samples, the challenges related to growth pattern identification and the absence of a complete baseline and individual variability (Wheeler \& Jones, 1989; Van Neer et al., 2004). For the Magdalenian period, salmonids are the most frequently recorded species from archaeological assemblages (Le Gall, 1999, 2008). Today, salmonids are an important group of both freshwater and anadromous fish distributed throughout the Holarctic region (Sanford, 2000). One of the lesser-studied species is the European grayling (Thymallus thymallus). For this reason, we 
chose to use it as the focus of our study, using scalimetry, in order to address important questions in both archaeology and biogeography. European graylings are distributed throughout a large part of the European continent, and are naturally present along the coast of western Wales and throughout Europe to the White Sea, Russia (Broughton, 1989; Kottelat \& Freyhof, 2007; Persat, 2011). However, during the last few decades, many factors such as water-flow regulation, pollution, destruction of natural habitats, predation and overfishing have contributed to a decrease in local population sizes throughout the European distribution range (Persat, 1996). This species is restricted to freshwater, unlike the arctic grayling, Thymallus arcticus, which can develop an anadromous strategy (Northcote, 1995). The ecological needs for grayling include good quality, cool, well-oxygenated water with a maximum temperature of $20^{\circ} \mathrm{C}$ (Kraiem \& Pattee, 1980); it also prefers to inhabit riffles in large rivers (Persat, 2011). Unlike other salmonids, graylings spawn in rivers at the beginning of spring, have a high growth rate (Persat, 2011), mature sexually in their third spring (3 years old) and are iteroparous (Persat, 2011). This study is the first sclerochronological analysis of grayling archaeological scales using scale reading, or scalimetry, which is a reliable tool for estimating age and growth in grayling (Baglinière \& Le Louarn, 1987). It aims to better define the fishing season of the grayling and consequently the period of human activities, and to obtain data of grayling growth during the Magdalenian by comparing archaeological and modern samples of grayling scales.

\section{Material and methods}

\subsection{Modern reference data}

Most of the material studied came from collections gathered between 1996 and 2008, across various geographical areas. A total of 68 wild grayling were collected from four European countries representing distinct climatic conditions (cold and temperate zones): France $(n=22)$, Switzerland $(n=16)$, Finland $(n=20)$ and Sweden $(n=10)$. The fish were caught in twelve localities (Pranlac in France; Saint-Bartélemy, Vallée de Joux and Eclagnens in Switzerland; Vaskojoki, Rommaeno, Näätämö and Juutua in Finland; and Kaitum, Vindelälven, Tjulander, Märsängen in Sweden) (fig.1). All individuals were measured according to their total length ( $\mathrm{TL} \pm 1 \mathrm{~mm}$ ). The fishing data (sampling date and area) were recorded. The mass ( $\mathrm{W} \pm 1 \mathrm{~g}$ ) was only taken for the Finnish and Swedish specimens. Three scales were selected from each specimen and only the clearest ones were analyzed. 


\subsection{Archaeological material}

Le Taillis des Coteaux (TDC) cave in Antigny (46³7'17"N - $0^{\circ} 46^{\prime} 11^{\prime \prime} \mathrm{W}$, France) was discovered in 1998, and has been continuously excavated since 2000 under the direction of Jérôme Primault. This cave is located on the right bank of the Gartempe river, part of the Loire basin. The preserved stratigraphy is exceptional and covers the Upper Paleolithic from the Aurignacian to the Middle Magdalenian (Primault et al., 2007).

The main Magdalenian occupation is evidenced by lithic artefacts and bone remains. Two phases of this culture were documented and dated. For the Lower Magdalenian, radiocarbon ages range from $17460 \pm 110 \mathrm{BP}(\mathrm{Ly}-6407)$ to $16900 \pm 100 \mathrm{BP}$ (Ly-6409), and for the Middle Magdalenian between $15280 \pm 90$ BP (Ly-6408) and $15140 \pm 80$ BP (Ly-6410). During the excavations, the anatomic elements of fish were collected by water-sieving (1.8 $\mathrm{mm}$ mesh). Archaeological grayling scales were identified by comparison with the reference collection of the Muséum national d'histoire naturelle (MNHN, Paris). From a total of 9887 fish scales, 5342 (54\%) belonged to grayling; however, only complete scales with undamaged margin were selected for further investigation.

All scales came from the Lower Magdalenian levels (IIIa, b, c) of TDC (Guillaud, 2014). Initially, 50 archaeological scales were selected but, after removing incomplete and regenerated scales, only fifteen were considered in a suitable condition for growth rings counting (Fig. 2).

The growth rate of the French Paleolithic grayling was estimated by using back-calculation. Back-calculated lengths to a specific age were obtained, providing the relationship between the fish length and scale size. The length of archaeological grayling was established using the functional regression between total length (TL) and scale radius length.

\subsection{Scale images analysis}

Growth marks (or annuli) were identified for each scale, and counted to estimate the age of the fish; growth increments were automatically measured continuously from the focus to the distal margin. The scales were then observed under transmitted light with a stereomicroscope equipped with a digital camera. The software program TNPC 7.0 (digital processing of calcified structures, $\underline{\text { www.TNPC.fr) }}$ ) was used to collect, process and store the 
data in a database. Regarding the age of the specimens, scales were independently interpreted by two specialists in order to limit interpretation bias. With regard to the growth rates, backcalculation of fish length was used.

Based on the age estimation and the scale length/fish total length relationship, body sizes at age were back-calculated for archaeological individuals assuming proportional constant growth between the scale and body of the fish (Francis, 1990; Ombredane \& Baglinière, 1992; Pierce et al., 1996).

To estimate the periodicity of increment formation, marginal increment analysis (MIA;

Beamish \& McFarlane, 1983) was carried out on modern scales by calculating the monthly marginal increment (MI) according to the following formula: $\mathrm{MI}=\left(\mathrm{R}-\mathrm{r}_{\mathrm{n}}\right) /\left(\mathrm{r}_{\mathrm{n}}-\mathrm{r}_{\mathrm{n}-1}\right)$

Where $\mathrm{R}$ is the scale radius, $r_{n}$ is the distance between the edge and the last growth ring and $r_{n-1}$ is the distance between the edge and the second last growth ring (Fig 3).

Age and total length data were used to describe the grayling growth using the Von Bertalanffy model $(1938,1960)$ according to the following formulae (Ricker, 1975):

Length growth: $\mathrm{TL}_{\mathrm{t}}=\mathrm{TL}_{\infty}\left(1-\mathrm{e}^{-\mathrm{K}(\mathrm{t}-\mathrm{t})} 0\right)$

Weight growth: $\mathrm{W}_{\mathrm{t}}=\mathrm{W}_{\infty}\left(1-\mathrm{e}^{-\mathrm{K}(\mathrm{t}-\mathrm{t})}\right)^{\mathrm{b}}$ avec $\mathrm{W}_{\infty}=\mathrm{a} \mathrm{TL}_{\infty}^{\mathrm{b}}$

Where $\mathrm{TL}_{t}$ and $\mathrm{W}_{t}$ are the predicted length and weight at age $t, \mathrm{TL}_{\infty}$ and $\mathrm{W}_{\infty}$ are asymptotic length and weight respectively. $\mathrm{K}$ is the growth coefficient; $\mathrm{t}_{0}$ is the theoretical age at zero length, and $\mathrm{b}$ the allometric coefficient.

Due to the limited size of the modern sample, the Von Bertalanffy model was established by combining all the specimens from each of the four countries.

\section{Results}

\subsection{Modern reference samples of scales}

The length (TL) of the modern graylings sampled ranged from 145 to $500 \mathrm{~mm}$ with a mean length of $360 \mathrm{~mm}$ (Standard Deviation =121). For Finnish specimens, the mean weight was around $849 \mathrm{~g}(\mathrm{SD}=237)$ (Tab. 1). The length-weight relationship was described by the equation: $\mathrm{W}=6 * 10^{-7} * \mathrm{TL}^{3.44}\left(\mathrm{n}=20 ; \mathrm{r}^{2}=0.86 ; \mathrm{p}<0.05\right)$, showing a significant positive allometric growth $(b=3.44)$.

Moreover, the total length-scale radius relationship $(\mathrm{TL}=0.061 * \mathrm{Rs} 143.53)$ showed a significant correlation of the two parameters $\left(n=68 ; r^{2}=0.82 ; \mathrm{p}<0.000\right)$. 
The smallest fish sampled were one year old, from France and Switzerland, while the oldest one (9 years old) came from Finland.

The MIA indicated an active period of growth from March to June. The mean of the distance between the last growth ring and the scale edge increased during the growth season. In June, a slowdown in growth was observed, followed by a new growing phase in July (Fig. 4). The high value in October is explained by the presence of a single 3-year-old Swiss specimen.

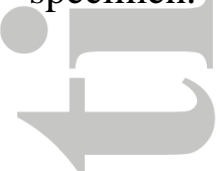

The Von Bertalanffy growth model was computed from the lengths and estimated ages of all graylings of each age class of the combined monthly samples. The Von Bertalanffy growth parameters (Fig. 5) were estimated for all 68 modern specimens:

$\mathrm{TL}_{\infty}=544 \mathrm{~mm} ; \mathrm{K}=0.19 \mathrm{yr}^{-1}$ and $\mathrm{t}_{0}=1.4$ year.

These results were compared to another growth model from Switzerland using 95 modern specimens: $\mathrm{TL}=385 \mathrm{~mm} ; \mathrm{K}=0.40 \mathrm{yr}^{-1}$ and $\mathrm{t}_{0}=21$ hours (Paquet, 2002).

Comparison of the two growth models suggested that graylings from Switzerland (Paquet, 2002) are relatively slow growing. Therefore, because our data came from four European countries, with distinct seasonal variations, the growth of archeological fish was compared to the Swiss model (Paquet, 2002).

\subsection{Archaeological results}

Following the Swiss model, the archaeological grayling population would have grown in a similar way to that of the current cold water population. By comparing our archaeological data with Paquet's (2002) data, the archaeological grayling showed a growth rate and longevity that corresponded to the modern grayling from cold rivers, such as in Sweden. However, our results remain hypothetical, as they were obtained from a limited number of scales from specimens of disparate ages.

Using the statistical model, the archaeological individuals were calculated as having a TL of between 323 and $405 \mathrm{~mm}$; and were comparable, in size, to the Finnish specimens, with an estimated weight range of between 256 and $558 \mathrm{~g}$. Their age distribution obtained 
from the scales, for most of archaeological graylings, ranged from 6 to a maximum of 9 years old. This longevity corresponds with the results of the cold river population.

Comparing the MIA trend of modern scales with the individual MI of the archeological scales, the period of fish death at TDC could be estimated. The majority of scales $(n=12)$ had a relatively large growth zone at the edge, which suggests capture during the first semester of the year (from March to June). However, analysis of three scales showed that some were captured during winter (between September and February). We can conclude, therefore, that at the TDC site, during the Lower Magdalenian, fishing was mainly conducted during the spring (Fig. 6).

This study has generated valuable life history data that informs on the biology of Thymallus thymallus by providing validated age and growth parameters. Data suggests that the TDC grayling had a slower growth rate, took longer to reach maturity and had a greater longevity than modern grayling populations currently found in France.

\section{Discussion}

In agreement with Casteel (1974a, b), it is recognized that numerous elements (mainly scales, otoliths and vertebrae) can be used to reconstruct fish age, size and weight. This study focused solely on the information provided by scales (scalimetry study). The relationship between the scales and the fish's body size are dependent on a set of factors which include the location of scale removal from the fish's body, the sex and age of the fish, the environmental conditions and the type of regression model used (Ombredane \& Baglinière, 1992). For scalimetric studies, there are two different approaches: the diagonal transect or the anterior transect. Hurley et al. (1997) considered that the radius to the edge is easier to interpret than any other radius.

\subsection{Methods}

Our objective to optimize specific information using the scales was fully achieved using the Von Bertalanffy and marginal increment methods. Our results are extremely encouraging for future studies, and further archaeological applications on TDC material. However, as with all similar approaches, this method is entirely dependent on a sound modern reference collection. Our reference sample needs to be expanded to include more variability and increase its 
efficiency and reliability. As a consequence, our results should be analyzed cautiously, as a trend rather than a definitive conclusion.

\subsection{Archaeological information}

Good preservation of the scales edge allows estimating the season of capture. The analysis of growth rings indicates that graylings were generally captured during the spring period, probably from March to June. This estimate is supported by the study of macro fauna at the TDC site, specifically reindeer. The analysis of incremental growth marks in the cementum of reindeer teeth indicates that they were hunted during the spring/summer season (Gay \& Griggo, 2013).

Using back-calculated fish length, the comparison between modern and archaeological grayling showed a contemporary growth reduction that might be related to the effects of human activity (exploitation, habitat and water quality degradation). Analysis of the archaeological samples seems to demonstrate that fishing pressure due to human activity was low during this period.

To compare the development of archaeological and modern graylings, we need to collect more information about the growth seasonal variability during the Magdalenian period, and the thermal evolution of the Gartempe river through time. As cold spells result in the migration of fish to refuge areas (Le Gall, 2008), it is possible that graylings from the Loire basin developed in a specific biotope and did not contribute to the recolonization of northeast Europe. Persat et al. (2016) have already evidenced that the Loire basin graylings all shared a typical genetic profile. One can therefore hypothesize that these archaeological specimens came from a different population than those which recolonized Switzerland and Finland, etc. This may explain the difference in growth patterns between the French archaeological and modern foreign graylings.

The study of archaeological Salmonidae records provided an opportunity to understand climate fluctuations. In north-western Europe, there are several archaeological sites where salmonids have been identified from the Magdalenian period (Fig.7). Grayling remains are mentioned (Morel \& Müller, 1997; Street et al., 2006; Van Neer et al., 2007; Van Neer \& Wouters, 2007) from Germany (Andernach 1), Switzerland (Hauterive-Champréveyres 1 \& 2, Monruz) and Belgium (Trou de Chaleux, Trou du Frontal, Trou du Sureau, Bois laiterie and Walou cave). In France, this species was discovered at Bois des Brousses (Bazile \& 
Bazile 2010), Bois Ragot (Cravinho \& Desse-Berset, 2005) and Le Taillis des Coteaux (Guillaud, 2014).

In modern-day France, European graylings have been identified in the Rhine, Allier and Rhône basins (Keith et al., 2011), and have been successfully reintroduced in the Dordogne, Basse-Normandie, Béarn, Côte d'Or and Haute-Marne (Keith et al., 2011). Recently, a population from the Vienne river has been recognized as being potentially native (Persat et al., 2016). Generally, the presence of grayling in the faunal composition, coupled with an absence of cyprinids, indicates that fishing occurred in a specific zone almost exclusively inhabited by salmonids. Since the thermal tolerance of European grayling does not exceed $20^{\circ} \mathrm{C}$ (Kraiem \& Pattee, 1980), cold freshwater rivers offer the most likely picture of central and northern France during the Magdalenian. With regards to the biology of the species identified at TDC, the association of salmonids corresponds to a cool well-oxygenated river with a predominantly gravel-cobble substrate. The fishes' size, modeled from the archaeological scales, showed individuals which ranged from 323 to $405 \mathrm{~mm}$. Consequently, these results may also be indicative of the fishing techniques employed by local populations: selective line fishing or capture during the spawning season, in shallow waters (Persat, 2011) when the fish were more vulnerable. Consequently, fish scales can also inform as to the technological skills of the Magdalenian groups.

\subsection{Evidence for the human use of fish}

Fish remains are easily recognizable and have been recovered, often in abundance, from numerous archaeological sites. However, the origins of such assemblages are not always fully understood. The ability to create small fish bone accumulations is restricted to only a small number of predators including raptors, carnivores and humans. In order to recognize the agents responsible for these concentrations, we investigated the taphonomy of fish remains at TDC (Guillaud, 2014). We were able to exclude a contribution by carnivores, but we cannot separate avian from human contributions. During the Paleolithic, fish were caught mainly with harpoons, weirs or nets. Unfortunately, these fishing implements are almost never retrieved due to their organic nature. In the rare cases that they are, they are generally too badly damaged to enable successful interpretation (Cleyet-Merle, 1990). No direct evidence of fishing artefacts was found at the TDC site; though our data, similar to that of Bois-Ragot, 
La Garenne and L'Abri Fritsch (Meunier, 2004; Cravinho \& Desse-Berset, 2005), reveals that Salmonidae made up the major part of the fish accumulated. Compared to Butler's (1993) studies, we have uneven representations of cranial and post-cranial elements and low skeletal completeness. This feature better corresponds to cultural deposits, but is not sufficient to attest to the human origins of the material. The parietal art also offers evidence that humans interacted with Salmonidae. From among the 89 representations of recognized Salmonidae found throughout the Upper Paleolithic in Europe, two graylings were identified (Citerne, 2003): one at the Chaffaud cave (Savigné, Vienne) and one at the Raymonden rock shelter (Chancelade, Dordogne). Other salmonid representations belonged to salmon (26) and trout (8), with two being clearly attributable to sea trout (Citerne, 2003). These representations, combined with the numerous sites which have produced fish remains, demonstrate that Magdalenians were not only familiar with the aquatic environment, but were also extremely skilled fishermen.

\section{Conclusion}

Seasonality studies in archaeology also make it possible to obtain information about site occupation. Scale analysis studies allow an overview of the environment to be obtained through the growth rate of fish. However, the use of this method has several limitations; in particular it is affected both by the limited size of the archaeological sample and by the conservation state of the external edge of the scales. In this study, we clearly demonstrated the usefulness of sclerochronology when applied to archaeological fish scales. This method enabled the relationship between the occupancy rate of an archaeological site by humans, and their subsequent fishing activity to be determined. The results of this study can be applied to archaeological investigations of seasonality and fish capture strategies, which can then be used to interpret the role of fish in prehistoric diet and subsistence. In addition, this analysis enables the identification of biological characteristics and the life conditions of fish populations during this period.

As a consequence, we have evidenced that a fine knowledge of the faunal spectrum at TDC Paleolithic site allows to perform better environmental interpretations, specially about fish biology and yearly circle human activity. Hopefully, these results will encourage further studies using sclerochronology on fish scales, when and where they are available, as they have numerous applications and will significantly improve our understanding of fish resource fluctuations through time. 


\section{Acknowledgements}

This study was funded by a doctoral fellowship granted by the Muséum national d'histoire naturelle (Paris). We would also like to thank the Sclerochronology Centre of the IFREMER. Many people deserve recognition for their contributions: we are grateful to Jérôme Primault for providing access to the archaeological collection; to Henri Persat, Frédéric Hofmann, Nina Peuhkuri and Ari Savikko for their availability and the loan of scales which enabled this study and Jean-Luc Baglinière for his valuable comments. We also thank Alena Kovacova for her help with the English proofs and Jill Cucchi for copy-editing.

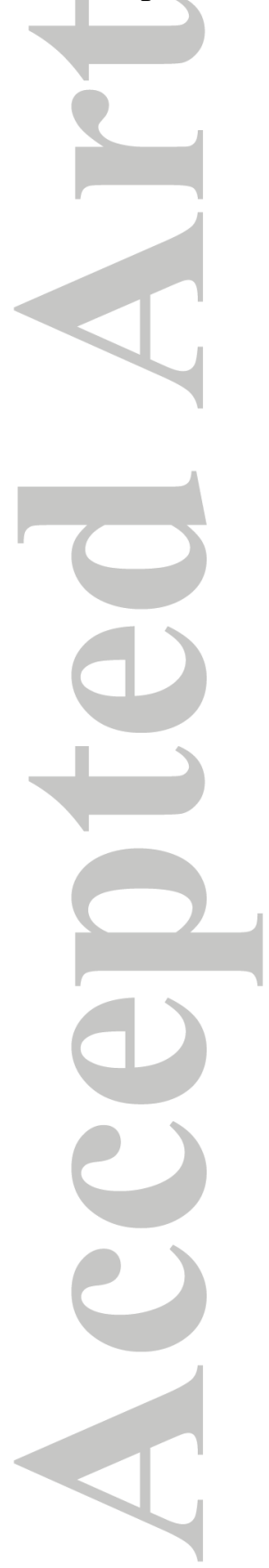




\section{References}

Baglinière JL, Le Louarn H. 1987. Caractéristiques scalimétriques des principales espèces de poisson d'eau douce en France. Bulletin Français de la Pêche et de la Pisciculture 306: 139. DOI : http://dx.doi.org/10.1051/kmae:1987005

Bazile F, Bazile C. 2010. Une structure pour le fumage du poisson au Bois des Brousses Aniane, Hérault. Expérimentation et interprétation de la structure pierreuse du niveau 2B. Etudes héraultaises 40: 19-29.

Beamish RJ, McFarlane GA. 1983. The forgotten requirement for age validation in fisheries biology. Transactions of American Fisheries Society 112(6): 735-743.

Bolle LJ, Rijnsdorp AD, Van Neer W, Millner, RS, Van Leeuwen PI, Ervynck A, Ayers R, Ongenae E. 2004. Growth changes in plaice, cod, haddock and saithe in the North Sea: a comparison of (post-)medieval and present-day growth rates based on otolith measurements. Journal of Sea Research 51: 313-328. DOI: 10.1016/j.seares.2004.01.001

Broughton R. 1989. Grayling: The fourth game fish. The Crowood Press. Ramsbury: Marlborough.

Buisson L, Thuiller W, Lek S, LIM P, Grenouillet G. 2008. Climate change hastens the turnover of stream fish assemblages. Global Change Biology 14: 2232-2248. DOI: 10.1111/j.1365-2486.2008.01657.x

Butler VL. 1993. Natural vs cultural salmonid remains origin of Dalles Roadcut, Columbia River, Oregon. Journal of Archaeological Science 20: 1-24. DOI: 10.1006/jasc.1993.1001

Casteel RW. 1972. Some Archaeological Uses of Fish Remains. American Antiquity 37(3): 404-419. DOI: $10.2307 / 278439$

Casteel RW. 1974a. A method for estimation of live weight of fish from the size of skeletal elements. American Antiquity 39: 94-98.

Casteel RW. 1974b.On remains of fish scales from archaeological sites. American Antiquity 39: $557-581$.

Citerne P. 2003. Les poissons dans l'art paléolithique: un thème figuratif au coeur de l'iconographie magdalénienne. $\mathrm{PhD}$, Université de Toulouse-le Mirail: Toulouse.

Cleyet-Merle JJ. 1990. La préhistoire de la pêche. Errance: Paris.

Cravinho S, Desse-Berset N. 2005. Les poissons du Bois-Ragot (Gouex, Vienne). In La grotte du Bois-Ragot à Gouex (Vienne): Magdalénien et Azilien: essais sur les hommes et leurs environnements. Chollet A, Dujardin V. (eds.). Société préhistorique française: Paris ; 355-371. 
Desse J, Desse-Berset N. 1993. Les poissons. In Les habitats du lac de Paladru (Isère) dans leur environnement. La formation d'un terroir au Xe siècle. Colardelle M, Verdel E (eds.). Documents d'Archéologie Française 40: 116-120.

Francis R. 1990. Back-calculation of fish length: A critical review. Journal of Fish Biology 36: 883-902. DOI : 10.1111/j.1095-8649.1990.tb05636.x

Gay I, Griggo C. 2013. Archéozologie du Magdalénien inférieur: étude cémentochronologique. In La grotte du Taillis des Coteaux, Antigny(Vienne). Fouille programmée tri-annuelle 2012-2014. Rapport intermédiaire 2013. Primault J, Astier A, Brou L, Béarez P, Ferrand J, Gabilleau J, Gaussein P, Gioe A, Griggo C, Guillaud E, Henry-Gambier D, Houmard C, Jeannet M, Laroulandie V, Le Fillâtre V, Lucquin A, Martin G, Pasquini A, Peschaux, C, Royer A. Rapport intermédiaire de la fouille programmée pluri-annuelle 2012-2014, Service Régional de l'Archéologie, Ministère de la culture et de la communication, préfecture de la région Poitou-Charentes, Direction régionale des affaires culturelles, 166-184.

Guillaud É. 2014. Étude archéo-ichtyofaunique des sites magdaléniens du Taillis des Coteaux et de La Piscine (vallée de la Gartempe, Vienne). Taphonomie, biodiversité et techniques de pêche. $\mathrm{PhD}$, Muséum national d'histoire naturelle: Paris.

Hales LS, Reitz EJ. 1992. Historical changes in age and growth of Atlantic croaker, Micropogonias undulatus (Perciformes: Sciaenidae). Journal of Archaeological Science 19: 73-99. DOI: 10.1016/0305-4403(92)90008-Q

Hurley KL, Pope KL, Pope Willis DW. 1997. Back-calculated length-at-age estimates from two scale radii. Prairie Naturalist 29: 229-236.

Keith P, Persat H, Feunteun E, Allardi J. 2011. Les poissons d'eau douce de France. Biotope, Muséum national d'histoire naturelle, collection Inventaires et Biodiversité : Paris.

Kottelat M, Freyhof J. 2007. Handbook of European freshwater fishes. Publications Kottelat, Cornol and Freyhof: Berlin.

Kraiem M, Pattee E. 1980. La tolérance à la température et au déficit en oxygène chez le barbeau (Barbus barbus L.) et d'autres espèces provenant des zones piscicoles voisines. Archiv für Hydrobiologie 88(2): 250-261.

Le Gall O. 1999. Ichtyophagie et pêches préhistoriques. Quelques données de l'Europe occidentale. Université de Bordeaux I : Bordeaux.

Le Gall O. 2008. Les poissons des eaux douces pléistocènes sont-ils des indicateurs paléoclimatiques? Une approche élargie à l'Europe. In Archéologie du poisson. 
Expérimentation et impacts, transformations et usages, paléoenvironnements. 30 ans d'archéo-ichtyologie au CNRS. Hommage aux travaux de Jean Desse et Nathalie Desse, Béarez P, Grouard S, Clavel B (eds.). 14th ICAZ Fish remains working group meeting. XXVIIIe rencontres. Edition APDCA: Antibes; 311-326.

Meunier FJ. 2004. Le matériel ichtyologique des grottes de la vallée moyenne de la Creuse. In Le coteau de la Garenne: Grand Abri et Grotte Blanchard, Saint-Marcel (Indre); Études 1999-2001, Tymula S, Paillet P. (eds.). PCR, Le Paléolithique de la vallée moyenne de la Creuse, ASSAAM : Saint-Marcel ; 33-36.

Morel P, Müller W. 1997. Hauterive-Champréveyres 11. Un campement magdalénien au bord du lac de Neuchâtel: étude archéozoologique (secteur 1). Archéologie neuchâteloise 23: $1-152$.

Northcote T. 1995. Comparative biology and management of Arctic and European grayling (Salmonidae, Thymallus). Reviews in fish biology and fisheries 5: 141-194. DOI: 10.1007/BF00179755

Ombredane D, Baglinière JL. 1992. Les écailles et leurs utilisations en écologie halieutique. In Tissus durs et âge individuel des vertébrés. Baglinière JL, Castanet J, Conand F, Meunier F (eds.). ORSTOM-INRA: Paris; 151-192.

Paquet G. 2002. Biologie et écologie de l'ombre commun (Thymallus thymallus) dans l'Orbe à la vallée de Joux, canton de Vaud. $\mathrm{PhD}$, Université de Lausanne: Lausanne.

Persat H. 1996, Threatened populations and conservation of the European grayling, Thymallus thymallus (L., 1758). In Conservation of Endangered freshwater fish in Europe. Kirchhofer A, Hefti D (eds.). Birkhäuser Verlag: Basel; 233-247. DOI : 10.1007/978-30348-9014-4_23

Persat H. 2011. L'Ombre commun Thymallus thymallus. In Les poissons d'eau douce de France. Keith P, Persat H, Feunteun E, Allardi J (eds.). Muséum national d'histoire naturelle: Paris; 413-415.

Persat H, Mattersdorfer K, Charlat S, Schenekar T, Weiss S. 2016. Genetic integrity of the European grayling (Thymallus thymallus) populations within the Vienne River drainage basin after five decades of stockings. Cybium 40(1): 7-20.

Pierce CL, Rasmussen JB, Leggett WC. 1996. Back-calculation of fish length from scales: Empirical comparison of proportional methods. Transactions of the American Fisheries Society 125: 889-898. 
Primault J, Brou L, Gabilleau J, Langlais M. 2007. La grotte du Taillis des Coteaux à Antigny (Vienne): intérêts d'une séquence originale à la structuration des premiers temps du Magdalénien. Bulletin de la Société Préhistorique Française 104(4): 743-758.

Ricker WE. 1975, Computation and interpretation of the biological statistics of fish populations. Bulletins of the Fisheries Research Board of Canada 191: 1-382.

Sanford CPJ. 2000. Salmonoid fish osteology and phylogeny (Teleostei: Salmonoidei). In: Theses Zoologicae 33, Fricke R (ed.). ARG Gantner Verlag: Ruggell; 1-264.

Smith HA. 1983. Determination of seasonality in archaeological sites through examination of fish otoliths: a case study. Journal of Field Archaeology 10(4): 498-500.

Street M, Gelhausen F, Grimm S, Moseler F, Niven L, Sensburg M, Turner E, Wenzel S, Jöris O. 2006. L'occupation du bassin de Neuwied (Rhénanie centrale, Allemagne) par les Magdaléniens et les groupes à Federmesser (aziliens). Bulletin de la Société préhistorique française 103(4): 753-780.

Van Neer W, Augustynen S, Linkowski, T. 1993. Daily growth increments on fish otoliths as seasonality indicators on archaeological sites: the tilapia from Late Palaeolithic Makhadma in Egypt. International Journal of Osteoarchaeology 3: 241-248. DOI: I047482X/93/040241-08\$09.00

Van Neer W, Ervynck A, Bolle LJ, Millner RS. 2004. Seasonality only works in certain parts of the year: the reconstruction of fishing seasons through otolith analysis. International Journal of Osteoarchaeology 14: 457-474. DOI: 10.1002/oa.727

Van Neer W, Lougas L, Rijnsdorp AD. 1999. Reconstructing age distribution, season of capture and growth rate of fish from archaeological sites based on otoliths and vertebrae. International Journal of Osteoarchaeology 9: 116-130. DOI: 10.1002/(SICI)10991212(199903/04)9:2<116::AID-OA465>3.0.CO;2-H

Van Neer W, Wouters W. 2007. Trooz/Dorêt: La pêche attestée au Paléolithique moyen et supérieur dans la grotte Walou. Chronique de l'Archéologie Wallone 14: 99-100.

Van Neer W, Wouters W, Germonpré M. 2007. Fish remains from three Upper Palaeolithic cave deposits in southern Belgium. Anthropologica et Praehistorica 118: 5-22.

Von Bertalanffy L. 1938. A quantitative theory of organic growth. Human Biology 10(2): 181-213.

Von Bertalanffy L. 1960. Principles and theory of growth. In Functional aspects of normal and malignant growth, Nowinsky WW. (ed.). Elsevier: Amsterdam; 137-259.

Wheeler A, Jones AKG. 1989. Fishes. Cambridge University Press. Cambridge.

Wood CM, McDonald G.1997. Global Warming - Implications for Freshwater and Marine Fish. Cambridge University Press: Cambridge. 


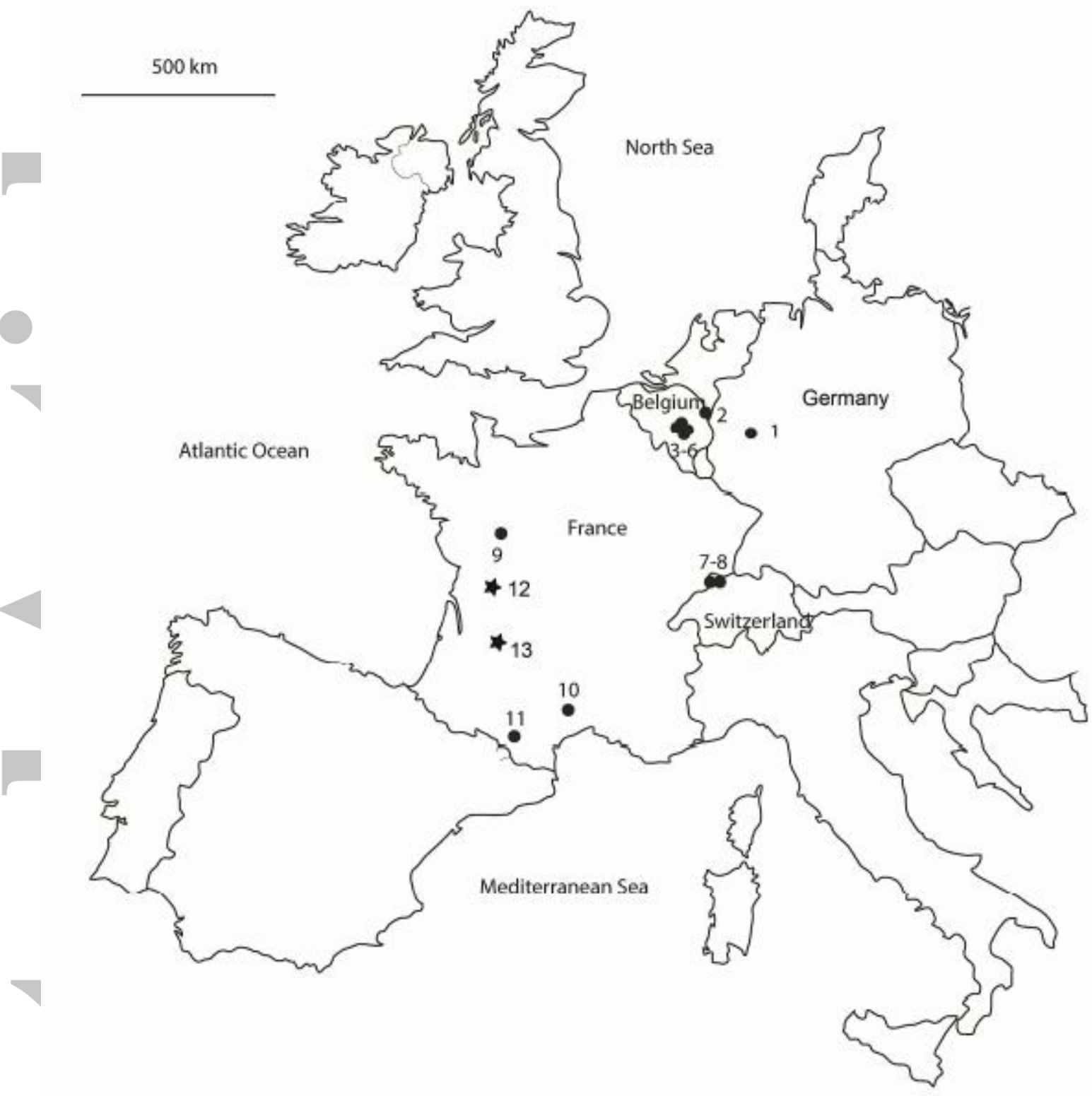

Figure 1: Site map of sampled current grayling populations: Finland: 1-Näätämö, 2Vaskojoki, 3-Juutua; Sweden: 4-Rommaeno, 5-Kaitum, 6-Vindelälven, 7-Tjulander, 8Marsängen; Switzerland: 9-Eclagnens, 10-Vallée de Joux, 11-Saint-Barthélemy; France: 12-Pranlac. 

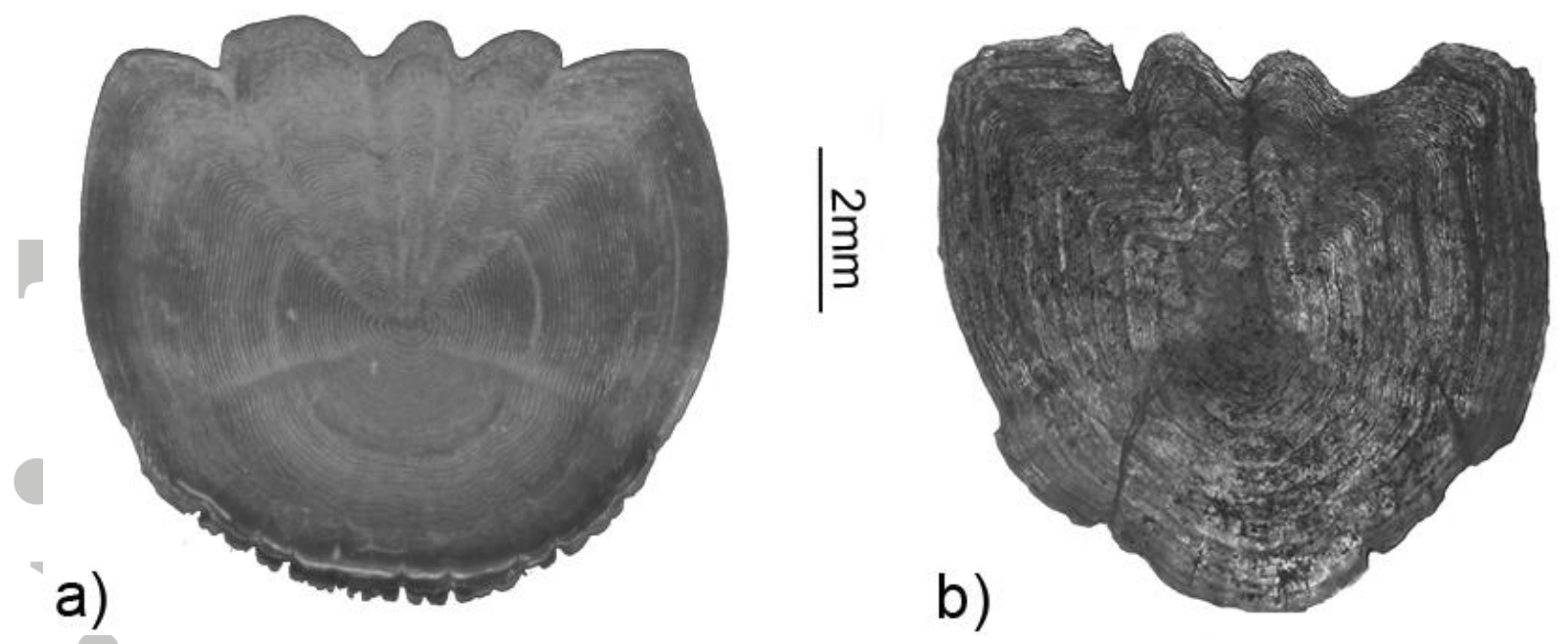

Figure 2: Grayling scale photography: a) modern scale; b) archaeological scale
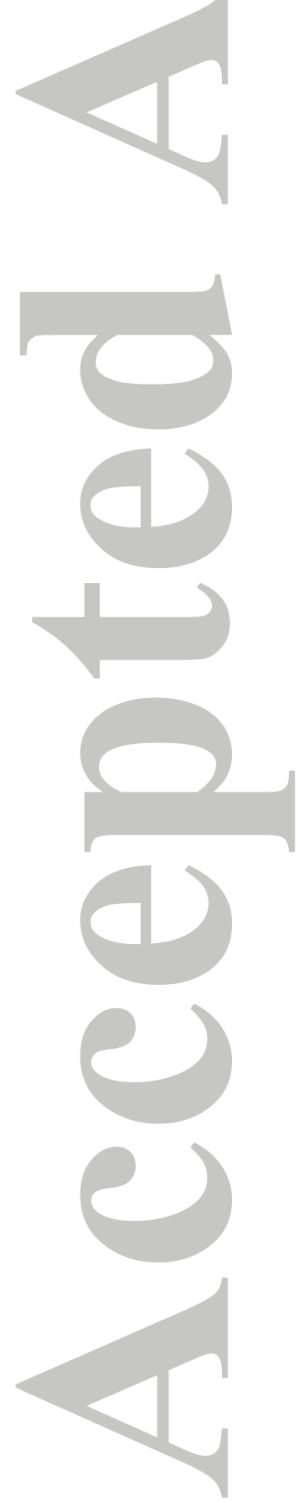

This article is protected by copyright. All rights reserved. 


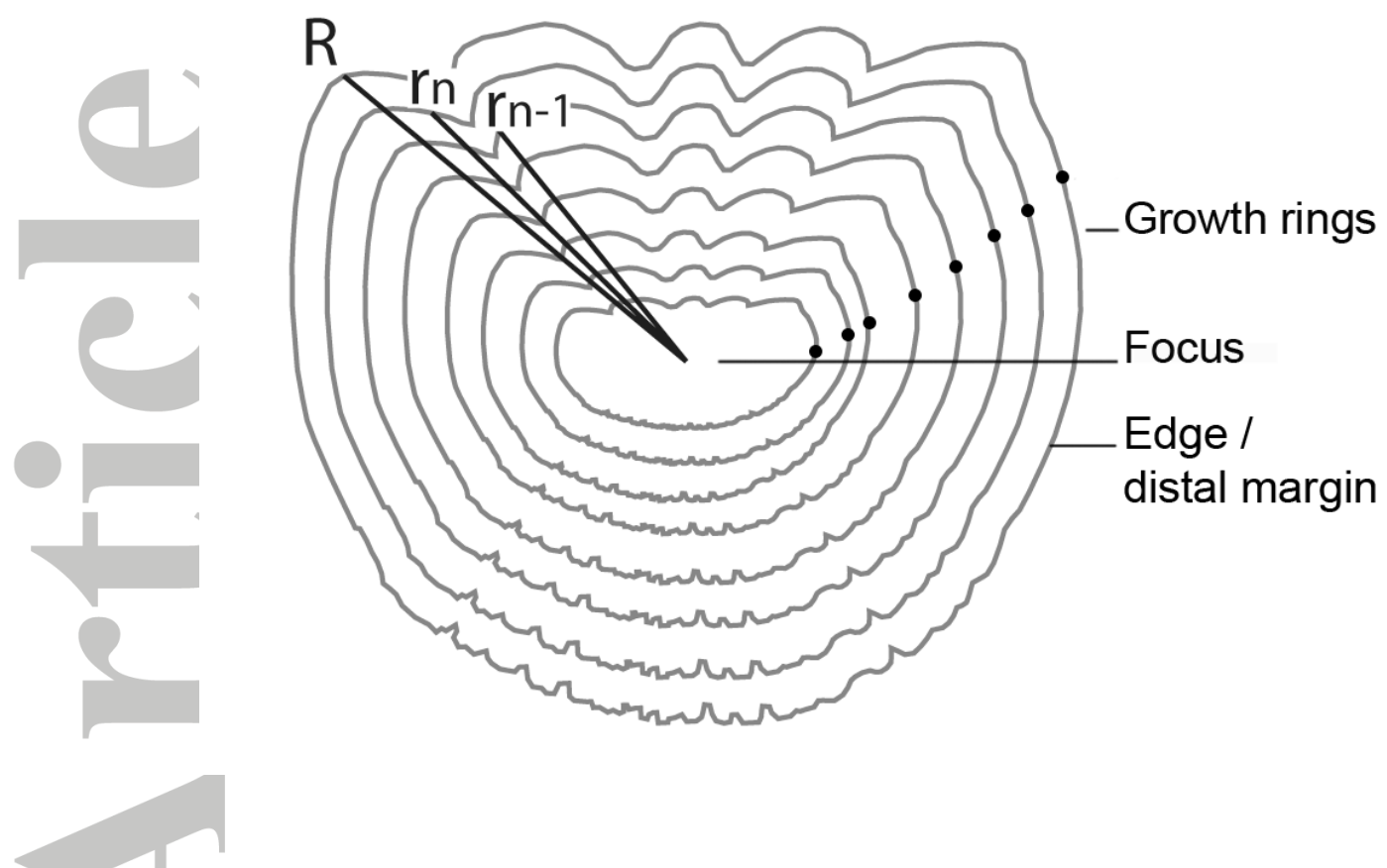

Figure 3: Description of Thymallus thymallus scale with the localization of the focus, the edge, the growth rings (or annuli) and the scale radii $\left(\mathrm{r}_{\mathrm{n}}\right)$.

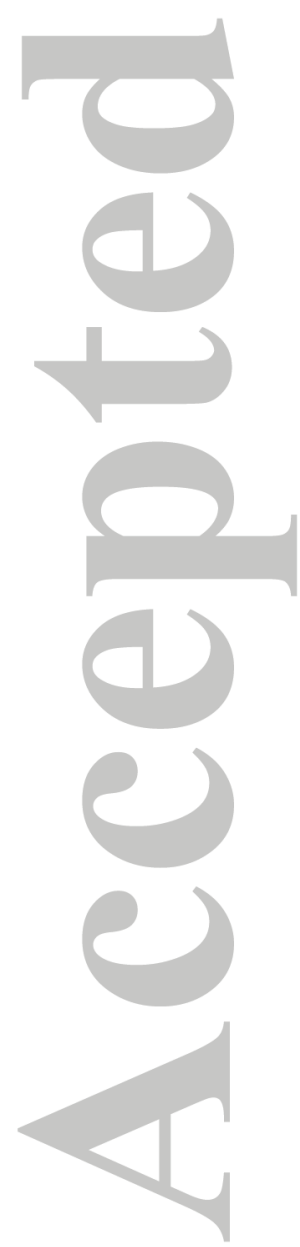




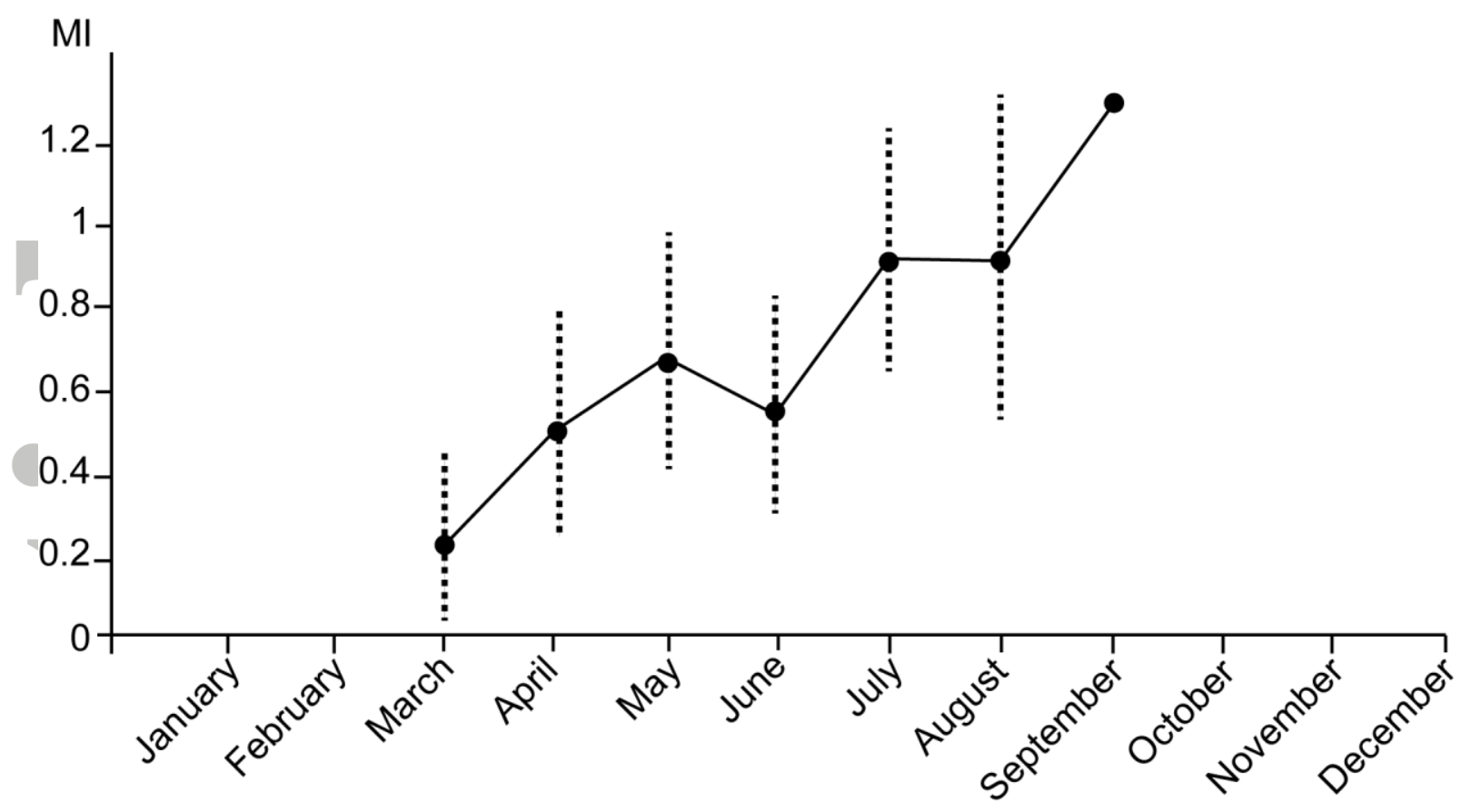

Figure 4: Marginal increment analysis and standard deviation performed on all modern specimens.

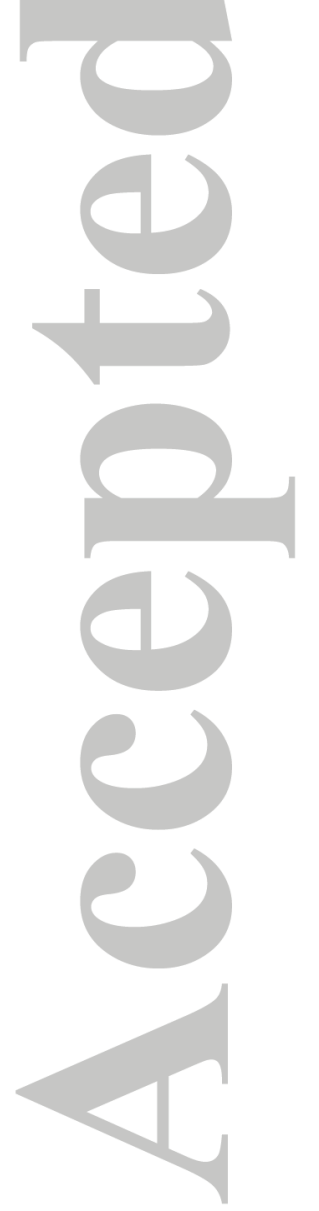




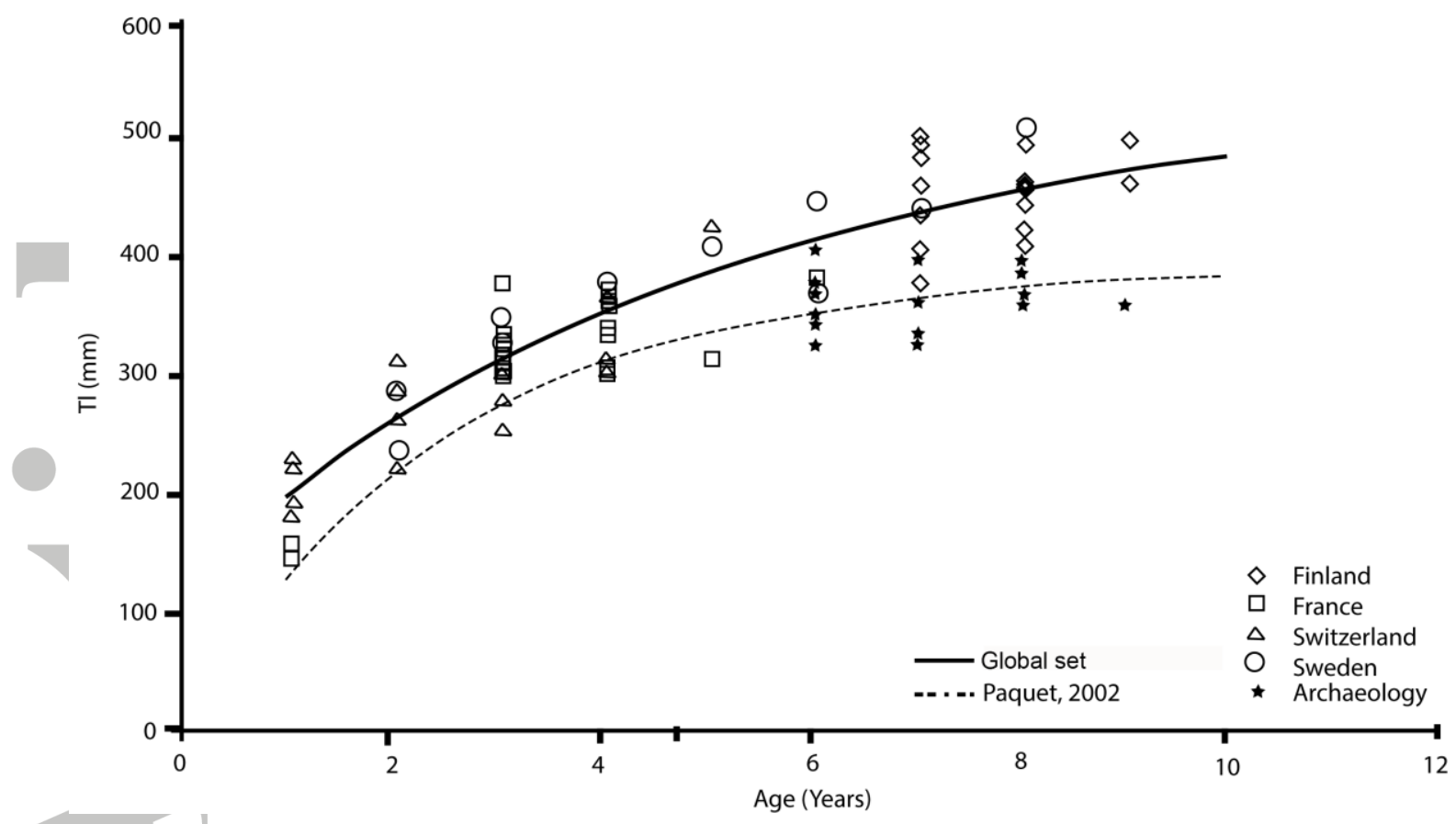

Figure 5: Von Bertalanffy growth models from the global set and Paquet (2002).

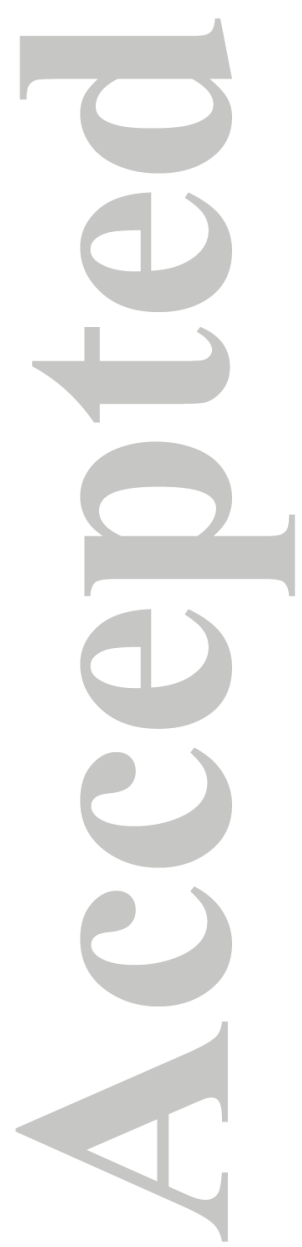




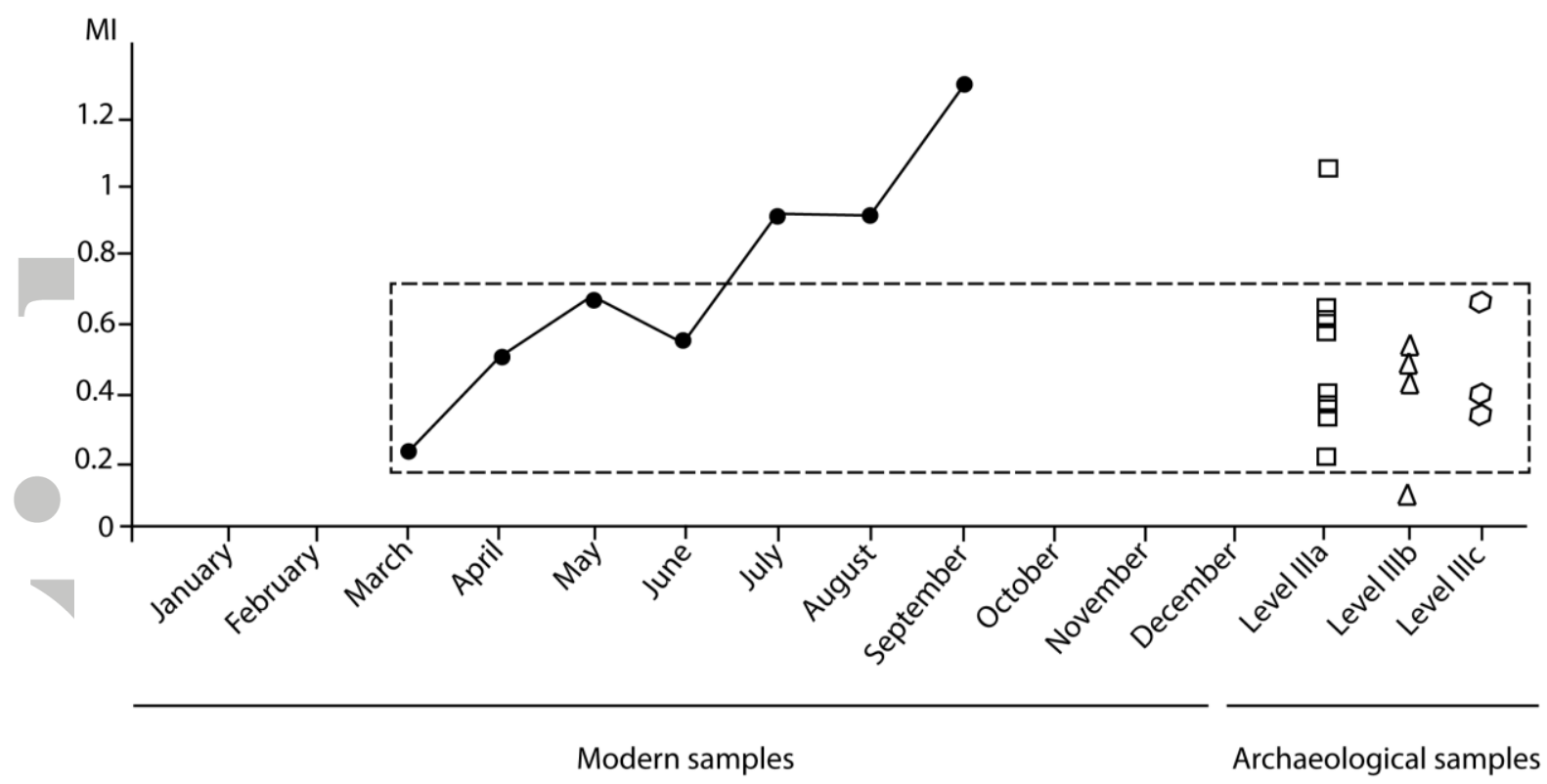

I-

Figure 6: Determination of capture season by comparison with the actual grayling reference model (all countries combined). 


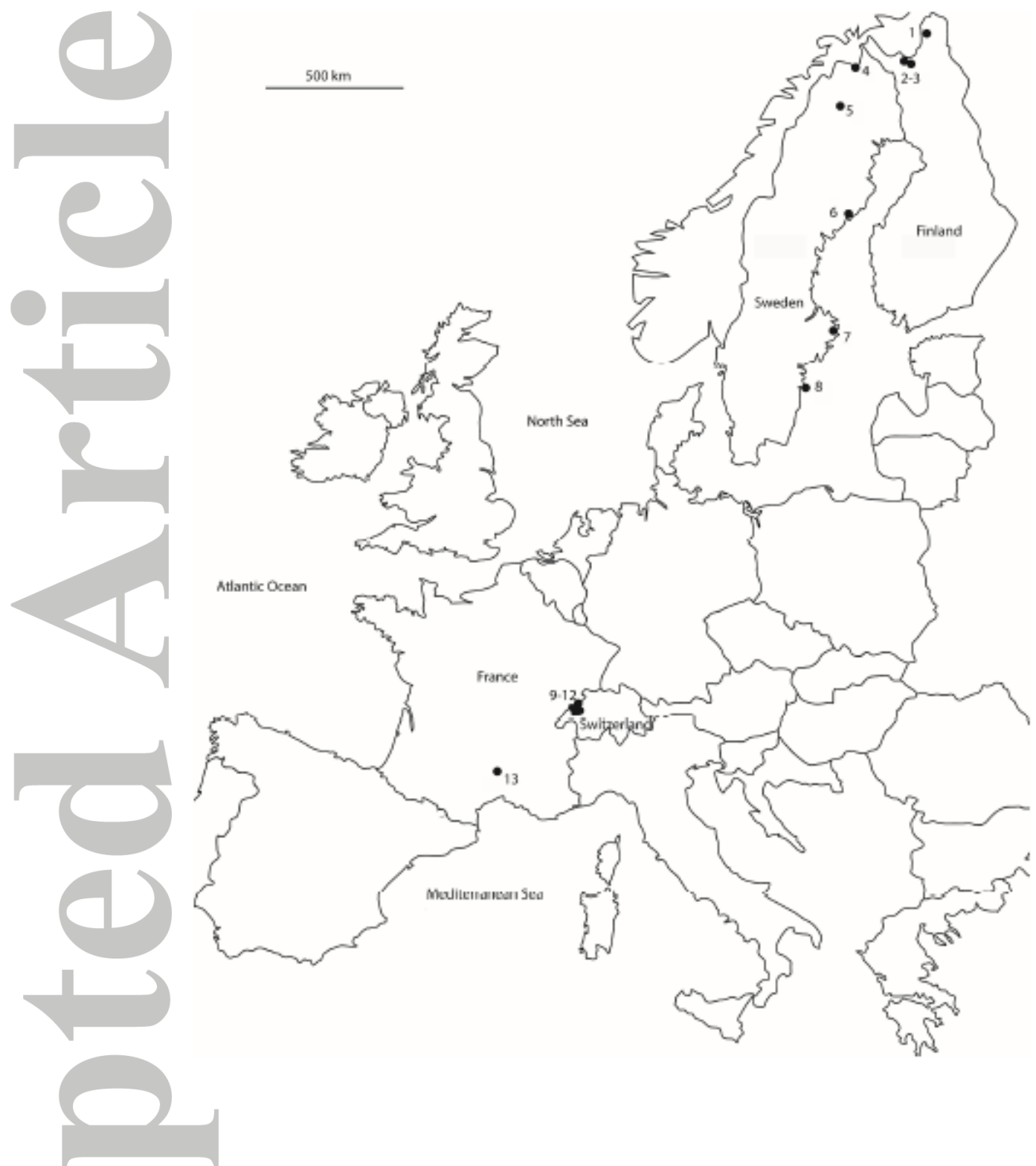

Figure 7: Location of sites mentioned in the text. Germany: 1-Andernach 1; Belgium: 2-

Walou cave, 3-Trou de Chaleux, 4-Trou du Frontal, 5-Trou du Sureau, 6-Bois laiterie;

Switzerland: 7-Hauterive-Champréveyres 1 \& 2, 8-Monruz; France: 9-Taillis des Coteaux, 10-Bois Ragot, 11-Bois des brousses; Parietal art. : 12-Chaffaud cave, 13-Raymonden rock shelter. 